\title{
Corrosion-erosion processes of the AA 5083 (Al-Mg) alloy in seawater
}

\section{Procesos de corrosión-erosión de la aleación AA 5083 (Al-Mg) en agua de mar}

\author{
A. Aballe ${ }^{1}$ \\ M. Bethencourt ${ }^{1 *}$ \\ F.J. Botana ${ }^{1}$ \\ M. $\operatorname{Marcos}^{2}$ \\ J.M. Sánchez-Amaya ${ }^{1}$ \\ ${ }^{1}$ Departamento de Ciencia de los Materiales e Ingeniería Metalúrgica y Química Inorgánica \\ Facultad de Ciencias del Mar \\ Universidad de Cádiz \\ Ave. República Saharaui s/n \\ Puerto Real, 11510-Cádiz, Spain \\ * E-mail: manuel.bethencourt@uca.es \\ 2 Departamento de Ingeniería Mecánica y Diseño Industrial \\ Escuela Superior de Ingeniería \\ Universidad de Cádiz \\ C/ Sacramento, 82 \\ 11003-Cádiz, Spain
}

Recibido en octubre de 2001; aceptado en septiembre de 2002

\begin{abstract}
Fourier Transforms are applied to analyse surface roughness profiles recorded on samples coming from corrosion-erosion assays. The information retrieved using this method clearly complements that revealed by the more classical roughness amplitude parameters. The analysis procedure here proposed can be applied not only to characterise the surface of corroded samples but, in general, to evaluate the quality of any surface after application of finishing treatments.
\end{abstract}

Key words: corrosion-erosion, roughness, Fourier Transform, surface quality.

\section{Resumen}

En este trabajo se propone el análisis de perfiles de rugosidad mediante Transformada de Fourier como herramienta de caracterización de muestras procedentes de ensayos de corrosión-erosión. Los resultados obtenidos indican que este método proporciona información complementaria a la suministrada por parámetros convencionales de rugosidad. El método propuesto puede ser aplicado no sólo en la caracterización de muestras corroídas sino que es aplicable, en general, en la evaluación de la calidad de acabados superficiales.

Palabras clave: corrosión-erosión, rugosidad, Transformadas de Fourier, calidad superficial.

\section{Introduction}

When a material is exposed to an erosion-corrosion process it suffers transformations which involve changes in its superficial texture. These transformations are related to the mechanism through which this process has been verified (Stack et al., 1996).

The study of the mechanism of erosion-corrosion processes is limited, due to the lack of instrumental techniques which allow to make a quantitative analysis of these textural changes.

The use of the superficial roughness technique is proposed in the present work to characterise the topography of samples proceeding from erosion-corrosion assays at a quantitative

\section{Introducción}

Cuando un material es sometido a un proceso de corrosiónerosión sufre una serie de transformaciones que se traducen en cambios en su textura superficial. Estas modificaciones están relacionadas con el mecanismo a través del cual se ha verificado dicho proceso (Stack et al., 1996).

Una de las causas que limitan el estudio de los mecanismos de los procesos de corrosión-erosión es la falta de técnicas instrumentales que permitan evaluar cuantitativamente dichos cambios texturales.

En el presente trabajo se propone utilizar la técnica de medida de la rugosidad superficial para caracterizar 
level. Fourier Transform has focused special attention on the analysis of roughness profiles.

\section{Experimental}

Roughness measurements included in this work were made using a M4Pi/CNOMO Perthometer from Perthen. A profile resolution of $12 \mathrm{~nm}$ and a scanned distance range from $250 \mu \mathrm{m}$ to $16 \mathrm{~mm}$ are attainable with this instrument. A PC running software was developed in our lab for the control of this device.

This study has been carried out on samples of Al-Mg AA5083 alloys coming from erosion-corrosion tests. The device used, a submerged jet, and the surrounding conditions of the tests have been described in Bethencourt et al. (1996). Concerning this experimental device, it's important to remark that it has been designed in our laboratory with the objective to perform high velocity tests, of up to $40 \mathrm{~m} / \mathrm{s}$, using a $3.5 \% \mathrm{NaCl}$ solution as a corrosive medium.

Theoretic considerations about roughness measurements

Surface roughness measurement is considered to be a basic technique to evaluate the quality of any surface after application of a finishing treatment (García de la Chica, 1993). In the common use of this technique, after recording the surface roughness profile, it is possible to calculate normalised parameters, which provide quantitative information on the analysed surface. In the literature, two families of parameters have been classically described, one of them related with the amplitude and the other with the shape of the profiles.

No doubt, amplitude parameters $\left(\mathrm{R}_{\mathrm{a}}, \mathrm{R}_{\mathrm{z}} \ldots\right)$ are used more frequently, while shape parameters are yet seldom at use. In fact, until very recently these parameters have been employed qualitatively and only since 1990 quantitative methods have been proposed for their evaluation (DIN, 1990).

One of the methods recommended in DIN 4776 to evaluate the shape of the profiles is based on the bearing ratio curves or Abbott-Firestone curve. As an example, in figure 1 these curves have been represented for three surfaces with extreme texture characteristics. The first one (fig. 1a), corresponds to a surface with homogeneous undulations. The second one (fig. 1b) corresponds to a surface with exceptional valleys of great depth with respect to the mean surface and, the third (fig. 1c) corresponds to a regular surface with some peaks of great altitude. The characterisation of actual surfaces can be obtained by means of a qualitative comparison of Abbott curves with one of the models represented in figure 1.

A second method to evaluate the shape of the profiles is based on the procurement of the Amplitude Density Function in the roughness profile (AENOR, 1986), equivalent to the Probability Density Function used in statistics. From these curves it is possible to calculate the skewness parameter of the distribution $\mathrm{S}_{\mathrm{k}}(\mathrm{AENOR}, 1986)$. In figure 1 we have indicated the value of the skew corresponding to each model. cuantitativamente la topografía de muestras procedentes de ensayos de corrosión-erosión. Se ha dedicado especial atención a la aplicación de la Transformada de Fourier en el análisis de los perfiles de rugosidad.

\section{Diseño experimental}

Los perfiles de rugosidad se han obtenido haciendo uso de un rugosímetro Perthometer, modelo M4Pi/CNOMO, de Perthen. Este equipo permite registrar perfiles de rugosidad con una resolución de hasta $12 \mathrm{~nm}$ y seleccionar distancias de barrido desde $250 \mathrm{~nm}$ hasta $16 \mathrm{~mm}$.

El estudio se ha realizado sobre muestras de la aleación de Al-Mg AA5083 procedentes de ensayos de corrosión-erosión. El dispositivo utilizado, de tipo jet sumergido, y las condiciones de los ensayos se encuentran descritas en Bethencourt et al. (1996). En relación con el dispositivo experimental hay que señalar que éste ha sido diseñado en nuestro laboratorio con el objetivo de poder realizar ensayos a alta velocidad, de hasta $40 \mathrm{~m} / \mathrm{s}$, utilizando como medio corrosivo una disolución de $\mathrm{NaCl}$ al 3.5\%.

Consideraciones teóricas sobre las medidas de rugosidad.

La rugosidad superficial es considerada una técnica básica para la medida de la calidad de acabados en superficies metálicas (García de la Chica, 1993). En las aplicaciones convencionales de la técnica, una vez registrado el perfil de rugosidad es posible calcular toda una serie de parámetros normalizados que proporcionan información cuantitativa de la superficie analizada. En la bibliografía se encuentran descritas, fundamentalmente, dos familias de parámetros: los relacionados con la amplitud del perfil y los relativos a su forma.

Sin duda, los parámetros de amplitud $\left(\mathrm{R}_{\mathrm{a}}, \mathrm{R}_{\mathrm{z}} \ldots\right)$ son los de uso más extendido, mientras que los de forma se encuentran aún poco implementados. De hecho, hasta muy recientemente estos parámetros han sido utilizados a nivel cualitativo y sólo a partir de 1990 se han propuesto métodos cuantitativos para su evaluación (DIN, 1990).

Uno de los métodos recomendados en la Norma DIN 4776, para evaluar la forma de los perfiles, es el basado en las curvas de la tasa de longitud portante del perfil o curvas de AbbottFirestone. A modo de ejemplo, en la figura 1 se han representado dichas curvas para tres superficies con características texturales límites. La primera de ellas (fig. 1a) corresponde a una superficie que presenta ondulaciones homogéneas; la segunda (fig. 1b) a una superficie con valles excepcionales de gran profundidad respecto de la superficie media; y la tercera (fig. 1c) corresponde a una superficie regular que presenta algunas crestas de gran altitud. La caracterización de superficies reales se puede realizar mediante una comparación cualitativa de sus curvas de Abbott con las de los modelos representados en la figura 1.

Un segundo método para evaluar la forma de los perfiles está basado en la obtención de la función de densidad de las 

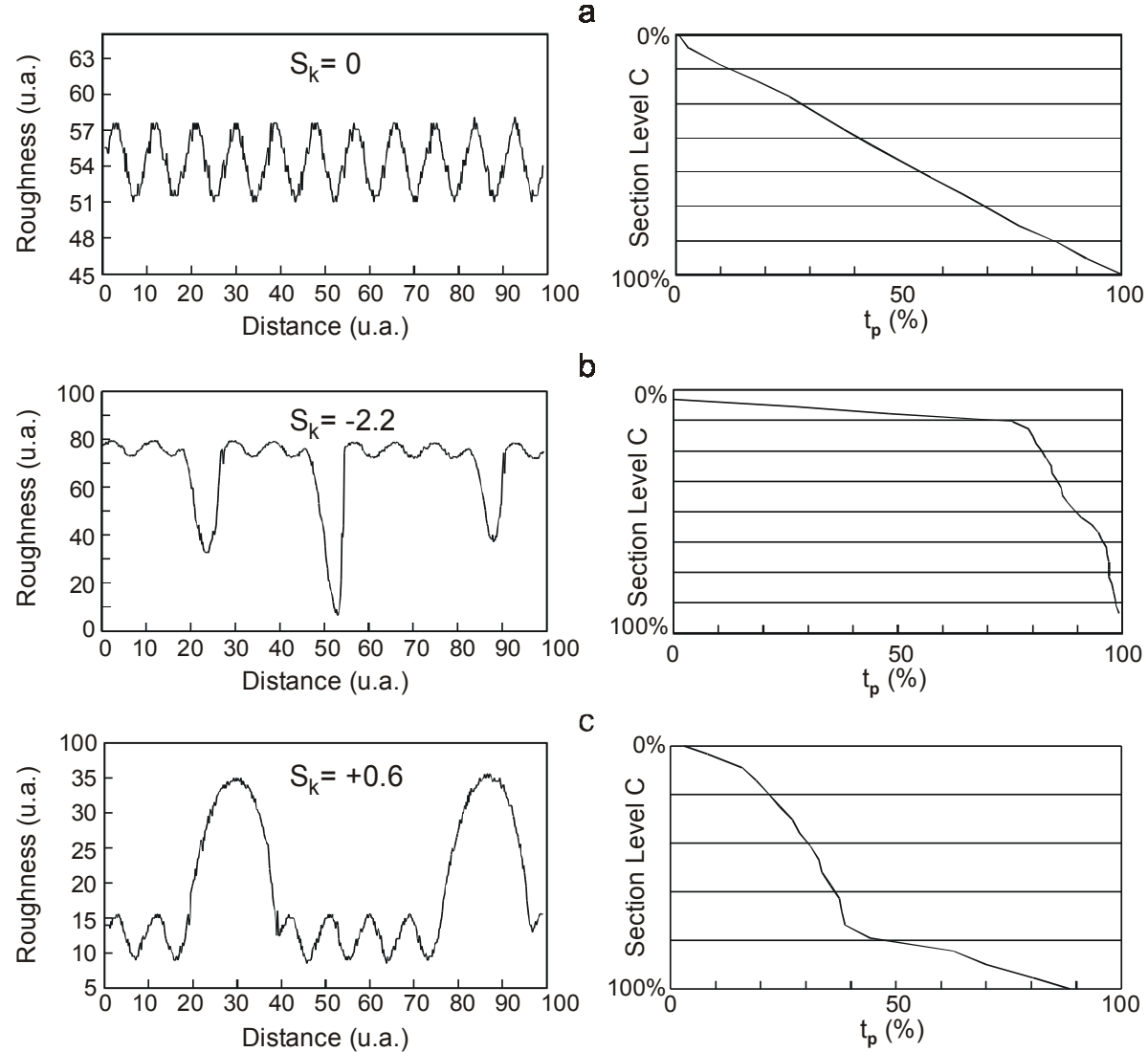

Figure 1. Roughness profiles and Abbott-Firestone curves corresponding to three different surface models: (a) Homogeneous waves, (b) rare valleys, and (c) rare mountains. Skewness values are indicated on the profiles.

Figura 1. Perfiles de rugosidad y curvas de Abbott-Firestone para tres superficies con características texturales límites. (a) Ondulaciones homogéneas, (b) valles excepcionales, y (c) crestas excepcionales. Los valores del sesgo $\left(S_{k}\right)$ se indican sobre los perfiles de rugosidad.

\section{Results and discussion}

In this section we presennt the results obtained from the application of the surface roughness technique to the characterisation of samples coming from erosion-corrosion tests. At this point, it is important to stand out that this technique has been scarcely used in the bibliography to characterize corroded samples and, if used, it was limited to the calculation of some amplitude parameters (Tomlinson and Matthews, 1994; Rao and Buckley, 1985).

In figure 2, the roughness profiles recorded on tested samples at different experimental conditions have been represented. In short, the S-1 sample has been subjected to the action of a $\mathrm{NaCl}$ dissolution moving at a velocity of $20 \mathrm{~m} / \mathrm{s}$, while the S-2 sample has been tested at $36 \mathrm{~m} / \mathrm{s}$. In this figure clear differences that exist between both profiles can be observed, as far as the amplitude and the shape are concerned. The differences in amplitude that exist between both profiles have been revealed through the corresponding values of $R_{a}$, which were 5.4 and 7.0 respectively.

With the aim of evaluating the differences that exist in the shape of the profiles, in figure 3 the Abbott-Firestone curves amplitudes en el perfil (AENOR, 1986), equivalente a la función de densidad de probabilidad utilizada en estadística. A partir de estas curvas es posible calcular el parámetro denominado sesgo de la distribución $\mathrm{S}_{\mathrm{k}}$ (AENOR, 1986). En la figura 1 se indica el valor del sesgo correspondiente a cada modelo.

\section{Resultados y discusión}

En este apartado se incluyen los resultados obtenidos al aplicar la técnica de medida de la rugosidad superficial a la caracterización de muestras procedentes de ensayos de corrosión-erosión. En este punto habría que indicar que esta técnica ha sido escasamente utilizada en la bibliografía en la caracterización de muestras corroídas. En los casos en que ha sido aplicada, su uso se ha restringido al cálculo de algunos parámetros de amplitud (Tomlinson y Matthews, 1994; Rao y Buckley, 1985).

En la figura 2 se representan los perfiles de rugosidad registrados sobre muestras ensayadas en distintas condiciones experimentales. Concretamente, la muestra S-1 ha sido sometida a la acción de una disolución de $\mathrm{NaCl}$ moviéndose a una velocidad de $20 \mathrm{~m} / \mathrm{s}$, mientras que la muestra S-2 fue ensayada 


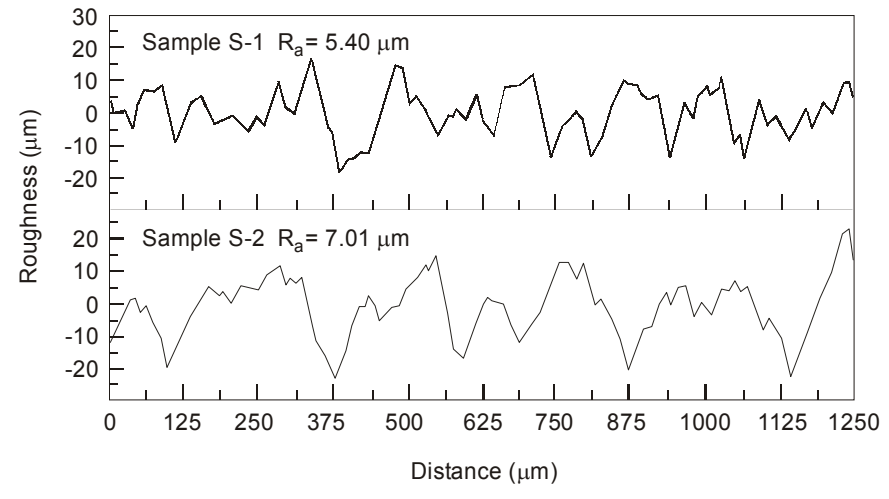

Figure 2. Roughness profiles recorded in the eroded zones of the samples (a) S-1 and (b) S-2 studied.

Figura 2. Perfiles de rugosidad registrados sobre las zonas erosionadas de las muestras (a) S-1 y (b) S-2 estudiadas.

have been plotted and the skew values obtained from the roughness profiles included in figure 2. The obtained results show no significant differences neither regarding the Abbott curves nor in the calculated values of the skew. It means that, if we use the parameters recently proposed in the literature to evaluate the shape of the roughness profiles, it is not possible to detect differences between the two studied samples. Therefore, these results suggest that no modifications in the texture of eroded samples were observed by increasing the fluid velocity in the assays.

The results disagree with the results obtained through studying the eroded samples by means of Scanning Electronic Microscopy (SEM). In figure 4, the SEM images acquired in the eroded zones of the samples S-1 and S-2 have been presented. In this figure we can observe the existence of large differences between both samples. Therefore, these results show that conventional shape parameters are not sensible enough to detect the changes produced in the erosion-corrosion tests.

In the present work, in order to improve the characterisation of the eroded samples, the application of a Fourier Transform treatment to the roughness profiles has been proposed. So, it is possible to obtain complementary a $36 \mathrm{~m} / \mathrm{s}$. En esta figura puede observarse que entre ambos perfiles existen claras diferencias tanto de amplitud como de forma. Las diferencias de amplitud existentes entre ambos perfiles se manifiestan a través de los correspondientes valores de $R_{a}$ que resultaron ser 5.4 y 7.0 respectivamente.

Con el objeto de evaluar las diferencias existentes en las formas de los perfiles, en la figura 3 se han representado las curvas de Abbott-Firestone y los valores del sesgo, obtenidos a partir de los perfiles de rugosidad incluidos en la figura 2. Los resultados obtenidos ponen de manifiesto que no existen diferencias significativas ni en el aspecto de las curvas de Abbot, ni en los valores calculados para el sesgo. Es decir, haciendo uso de los parámetros que actualmente se proponen en la bibliografía para evaluar la forma de los perfiles de rugosidad no es posible detectar diferencias entre las dos muestras estudiadas. Por tanto, estos resultados indicarían que el aumento en la velocidad del fluido en los ensayos no causa grandes modificaciones en la textura de las muestras erosionadas.

Esta conclusión no está de acuerdo con los resultados obtenidos al estudiar las muestras erosionadas, mediante Microscopía Electrónica de Barrido (MEB). En la figura 4, se presentan las imágenes de MEB adquiridas en las zonas erosionadas de las muestras S-1 y S-2. En ella puede observarse como existen claras diferencias texturales entre ambas muestras. Por tanto, estos resultados ponen de manifiesto que existe una cierta insensibilidad de los parámetros de forma convencionales para detectar los cambios que se producen en los ensayos de corrosión-erosión.

Con el fin de mejorar la caracterización de las muestras erosionadas, en el presente trabajo se propone realizar un tratamiento de los perfiles de rugosidad mediante Transformadas de Fourier. De esta manera, es posible obtener información cuantitativa complementaria a la proporcionada por los parámetros de amplitud y de forma convencionales.

Los perfiles de rugosidad, como los representados en la figura 2, pueden ser tratados matemáticamente como si fuesen el resultado de la superposición de ondas sinusoidales con distintas amplitudes, frecuencias y fases. Al realizar la Transformada Rápida de Fourier (FFT) de una señal experimental se obtendrían los valores de las frecuencias de cada una de las
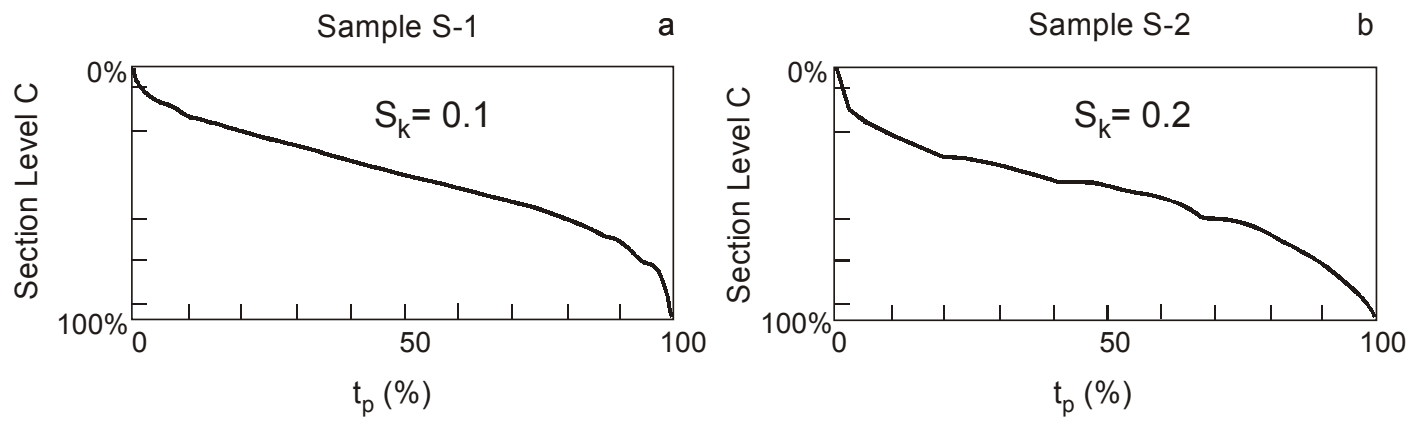

Figure 3. Abbot-Firestone curves and their corresponding skewness values calculated from roughness profiles recorded in the eroded zones of samples (a) S-1 and (b) S-2 .

Figura 3. Curvas de Abbott-Firestone y valores del sesgo calculados a partir de perfiles de rugosidad registrados en las zonas erosionadas de las muestras (a) S-1 y (b) S-2. 
S-1

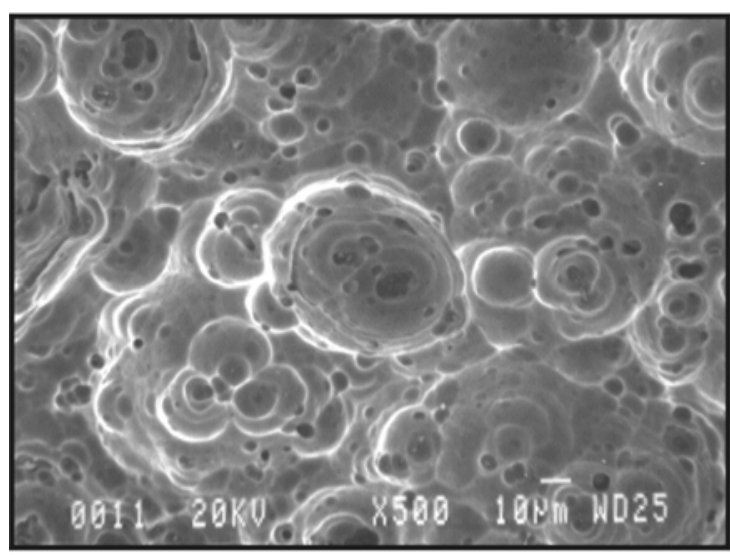

a

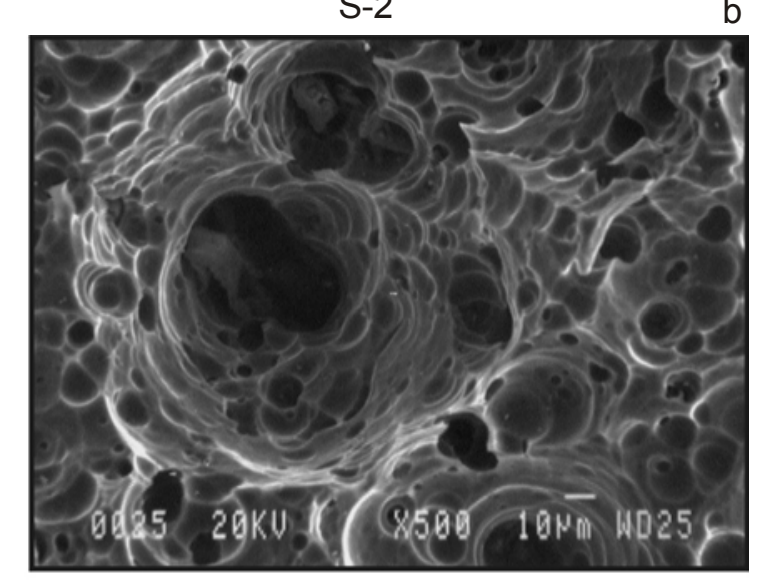

Figure 4. SEM images corresponding to the eroded zones of the samples (a) S-1 and (b) S-2.

Figura 4. Imágenes MEB adquiridas en las zonas erosionadas de las muestras (a) S-1 y (b) S-2.

quantitative information to the conventional shape and amplitude parameters provided.

Roughness profiles, as those represented in figure 2, can be mathematically treated as if they were the result of adding sinusoidal modulations with varying frequencies, phases and amplitudes. The Fast Fourier Transform operation provides values of frequencies, phases and amplitudes of each component present in the profile analysed (Champeney, 1973). These data are usually plotted as power spectra (PSD), which represents the amplitude of each component present in the profile versus the spatial frequency. In figure 5 , the power spectrum obtained applying the Fast Fourier Transform (FFT) to the experimental profiles in figure 2 , is presented.

In the power spectra corresponding to the sample S-1 (fig. 5b), we can observe that the larger intensity components appear in $0.01,0.015$ and $0.02 \mu \mathrm{m}^{-1}$. This indicates that the profile corresponding to sample S-1 can be considered to be formed by the addition of three sinusoidal modulations whose amplitudes and spatial frequency are shown in the power spectra. ondas armónicas que contribuyen al perfil, junto con el valor de la amplitud y la fase asociada a cada una de ellas (Champeney, 1973). Los resultados del análisis del perfil mediante FFT se pueden visualizar con facilidad al representarlos en forma de espectro de potencia (PSD), que es la representación frente al número de onda de la amplitud de cada una de las componentes presentes en el perfil. En la figura $5 \mathrm{se}$ han representado los espectros de potencia obtenidos al aplicar el método de FFT a los perfiles experimentales de la figura 2.

En el espectro de potencia correspondiente a la muestra S-1 (fig. 5a) se observa que las contribuciones de mayor intensidad aparecen centradas a $0.01,0.015$ y 0.02 micras $^{-1}$. Esto viene a indicar que el perfil correspondiente a la muestra S-1 puede considerarse formado, mayoritariamente, por la superposición de tres ondas sinusoidales cuyas amplitudes y números de onda quedan recogidos en el espectro de potencia.

La principal diferencia entre los PSD de las muestras S-1 y S-2 es que en la muestra ensayada a alta velocidad (fig. 5b) se produce un aumento considerable en la amplitud de la modulación de baja frecuencia, centrada a 0.005 micras $^{-1}$.
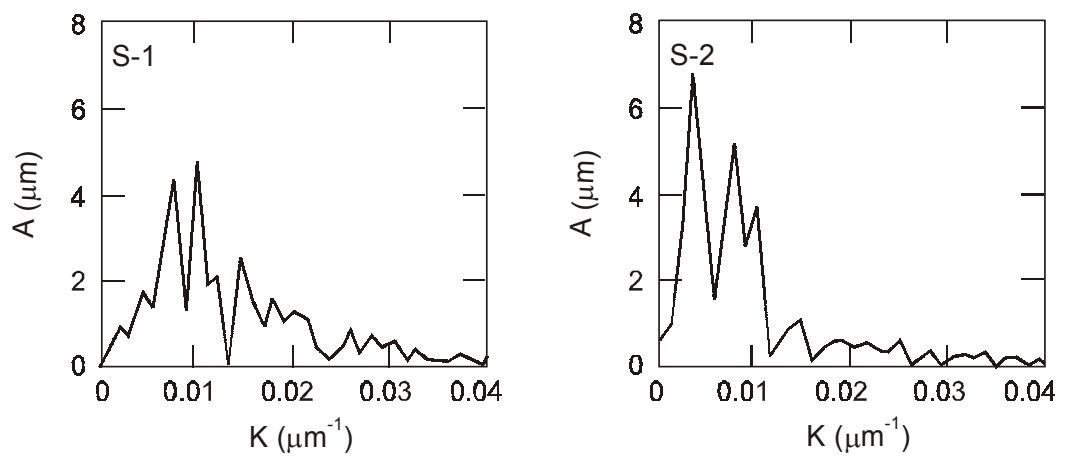

Figure 5. Plotted power spectra corresponding to the roughness profiles shown in figure 2.

Figura 5. Espectros de potencia correspondientes a los perfiles de rugosidad incluidos en la figura 2. 
The main difference between the PSD of the samples S-1 and S-2 is that in the sample assayed at high velocity (fig. 5b), the modulation of low frequency, centered at $0.005 \mu \mathrm{m}^{-1}$, increases considerable its amplitude.

Thus, through the FFT calculation of roughness profiles allowed to detect differences in the sample texture produced as a result of the increasing velocity of the fluid. In addition, this method presents the advantage, over other statistical parameters, of being readily related with the texture of the studied surface.

As indicated above, it is possible to calculate amplitude and phase for the wave centered in $0.005 \mu \mathrm{m}^{-1}$ from the PSD in figure $5 \mathrm{~b}$. This wave developed when the fluid velocity increased in the erosion-corrosion tests and is represented in figure 6 together with the roughness profiles for samples S-1 and S-2. In this figure it can be verified that the roughness profile for the sample assayed at high velocity is dominated by the $0.005 \mu \mathrm{m}^{-1}$ wave, while such wave is absent in the profile of the sample S-1.

These results indicate a clear relation between the increasing velocity of the corrosive medium producing textural changes on the surface of the samples. This changes create modulations of lower frequency than those developed in the test at low velocity. The wavelength of such undulations is similar to the biggest diameter pits observed in the SEM images in figure $4 \mathrm{~b}$.

\section{Conclusions}

This study showed that superficial roughness measurements can evaluate textural modifications in eroded samples due to varying velocities of the fluid. Nevertheless, if conventional parameters are used, only changes related to the amplitude of the profiles can be detected.

By using FFT to the experimental signals, we have been able to identify the frequency, amplitude and phase of each of the sine modulations generated in the surfaces as a result of the corrosive medium action. The results obtained indicate that the increase in the fluid velocity creates low frequency undulations in the surface. This kind of information is of interest to delve into the knowledge of corrosion-erosion process. Nevertheless, if correlations are to be established among the kind of modulation, the surrounding conditions of the tests and the mechanism of the process, it is necessary to apply this method to a higher number of tested samples in different experimental conditions.

Finally, is ought to that the Fourier analysis on roughness signals can be used to evaluate the quality of any surface after the application of finishing treatments. The results obtained in this work show that this kind of analysis provides complementary information to that given by conventional shape parameters.
Por tanto, mediante el cálculo de la FFT de los perfiles de rugosidad ha sido posible detectar las diferencias en la textura de las muestras que se ocasionan como consecuencia del aumento en la velocidad del fluido. Además, este método presenta la ventaja, frente a otros parámetros de tipo estadístico, de que la información que proporciona es fácilmente correlacionable con la textura de la superficie estudiada.

Como se ha comentado anteriormente, a partir del PSD de la figura $5 \mathrm{~b}$ es posible calcular la amplitud y la fase de la onda centrada a 0.005 micras $^{-1}$, que se desarrolla al aumentar la velocidad del fluido en los ensayos de corrosión-erosión. En la figura 6 se ha representado dicha onda junto con los perfiles de rugosidad de las muestras S-1 y S-2. En esta figura puede comprobarse como el perfil de rugosidad de la muestra ensayada a alta velocidad está dominado por la onda de 0.05 micras $^{-1}$, mientras que en el perfil de la muestra S-1 no se observa dicha onda.

En definitiva, estos resultados parecen indicar que al aumentar la velocidad del medio corrosivo se producen cambios texturales en la superficie de las muestras. Estos cambios se traducen en la aparición de ondulaciones de menor frecuencia que las que se desarrollan en los ensayos realizados a baja velocidad. La longitud de onda de dichas ondulaciones es semejante a las picaduras de mayor diámetro que se observan en la imagen MEB de la figura $4 b$.

\section{Conclusiones}

El estudio efectuado pone de manifiesto que las modificaciones texturales que se producen en las muestras erosionadas como consecuencia de la variación en la velocidad del fluido, pueden ser evaluadas mediante medidas de rugosidad superficial. No obstante, haciendo uso de los parámetros

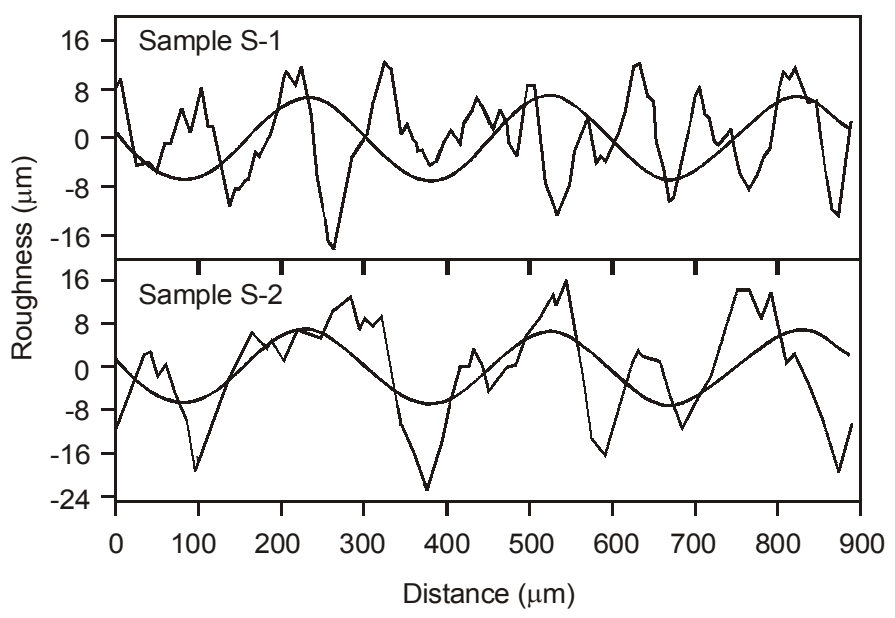

Figure 6. Roughness profiles recorded in the eroded zones of samples S-1 and S-2. A sine wave with a frequency of $0.005 \mu^{-1}$ has been superimposed on the profiles.

Figura 6. Perfiles de rugosidad de las zonas erosionadas de las muestras S-1 y S-2 junto con una onda de tipo seno de frecuencia $0.005 \mu \mathrm{m}^{-1}$. 


\section{Acknowledgements}

This work has been financed by the Comisión Interministerial de Ciencia y Tecnología (CICYT), Project MAT20013477.

\section{References}

Asociación Española de Normalización y Certificación (AENOR). (1986). Rugosidad superficial. Parámetros, sus valores y las reglas generales para la determinación de las especificaciones. Norma UNE 82-301-86. pp. 2-3.

Bethencourt, M., Botana, F.J., Calvino, J.J., Cauqui, M.A., Marcos, M. and Rodríguez-Chacón, M.A. (1996). Quantitative evaluation of erosion-corrosion effects in a jet submerged device. Proceedings of the $13^{\text {th }}$ International Corrosion Congress, Vol. II, paper 198. Australasian Corrosion Association. pp. 1-8.

Champeney, D.C. (1973) Fourier Transforms and Their Physical Applications. Academic Press, London. pp. 59-61.

Deutsches Institute für Normung (DIN). (1990). Parameters Rk, Rpk, Rvk, Mrl, Mr2 for the description of the material portion in the roughness profile; measuring conditions and evaluation procedures. Norma DIN 4776. pp. 4-5.

García de la Chica, A. (1993). Metrología del Acabado Superficial: Rugosidad, Colección Consejos para la Práctica Metrológica. Asociación Española para la Calidad, Madrid, pp. 16-17.

Rao, B.C.S. and Buckley, D.H. (1985). Erosion of aluminium 601-T6 under cavitation attack in mineral oil and water. Wear, 105: 171182.

Stack, M.M., Zhou S. and Newman, R.C. (1996). An approach to defining erosion-corrosion regimes for erosion corrosion in aqueous slurries. Proceedings of $13^{\text {th }}$ International Corrosion Congress, Vol. II, paper 191. Australasian Corrosion Association. pp. $1-4$.

Tomlinson, W.J. and Matthews S. J. (1994). Cavitation erosion of structural ceramics. J. Mat. Sci., 29: 1101-1108. convencionales sólo se han logrado detectar los cambios relacionados con la amplitud de los perfiles.

Al aplicar la FFT a señales experimentales ha sido posible identificar la frecuencia, amplitud y fase de cada una de las modulaciones de tipo seno generadas en las superficies como consecuencia de la acción del medio corrosivo. Los resultados obtenidos indican que un aumento en la velocidad del fluido provoca la aparición de ondulaciones de baja frecuencia en la superficie. Inicialmente, este tipo de información parece tener interés para profundizar en el conocimiento de los procesos de corrosión-erosión. No obstante, para llegar a establecer correlaciones entre el tipo de modulación, las condiciones de los ensayos y el mecanismo del proceso, se hace necesario aplicar el método a un mayor número de muestras ensayadas en diversas condiciones experimentales.

Por último, habría que decir que el análisis de Fourier de señales de rugosidad puede ser utilizado en la evaluación de la calidad de distintos acabados superficiales. Los resultados obtenidos en este trabajo ponen de manifiesto que este tipo de análisis proporciona información complementaria a la suministrada por parámetros de forma convencionales.

\section{Agradecimientos}

Este trabajo ha sido financiado por la Comisión Interministerial de Ciencia y Tecnología (CICYT), Proyecto MAT20013477 . 